\title{
Reimagining the Aapravasi Ghat: Khal TORABUlly's Poetry and THE INDENTUREd DiASPORA
}

\author{
Shanaaz Mohammed \\ Davidson College
}

\begin{abstract}
National narratives in Mauritius often affiliate the Indian diaspora with the experience of indentureship and the Aapravasi Ghat, a nineteenth century immigration depot classified in 2006 as a UNESCO World Heritage Site. This affiliation inevitably disregards the African, Malagasy, and Chinese laborers who also worked under the system of indenture in Mauritius during the nineteenth and twentieth centuries. In his 2013 collection of poetry, Voices from the Aapravasi Ghat: Indentured Imaginaries, Khal Torabully returns to the Aapravasi Ghat to recast the history of indentureship and highlight the various ethnicities of the indentured diaspora, their shared trauma, and displacement. This study contends that Torabully's poetic engagement with the Aapravasi Ghat, as an historical site of indentureship and its overlooked diversity, challenges the perception of the Ghat as a representation of Indian indentured memory. It uses Torabully's Coolitude poetics as a conceptual frame to consider the Aapravasi Ghat as an inaugural space that facilitated the creation of a complex, open-ended identity that aspires to promote a culture of diversity but not without its limitations and contradictions. Despite efforts to disrupt ethnic distinctiveness, Torabully reproduces Indo-centric perspectives expressed through the concept of kala pani and the fakir figure.
\end{abstract}

\section{INTRODUCTION}

In 2013 , to commemorate the $179^{\text {th }}$ anniversary of the arrival of indentured laborers in Mauritius, Khal Torabully published a collection of poetry entitled, Voices from the

(C) Shanaaz Mohammed. This is an Open Access article distributed under the terms of the Creative Commons License CC BY NC SA, which permits users to share, use, and remix the material provided they give proper attribution, the use is noncommercial, and any remixes/transformations of the work are shared under the same license as the original. 
Aapravasi Ghat: Indentured Imaginaries. ${ }^{1}$ The collection recognizes the history and memory of the indentured diaspora and represents a celebration of shared histories of laborers at the first British colony to receive indentured servants. This paper examines Torabully's engagement with the Aapravasi Ghat as an historical space that recognizes indentured migration and its resulting historical trauma and acknowledges the positive possibilities of diasporic identity building that emerged from that experience. In his poetry, Torabully sheds light on the many ethnicities that were part of the system of indentured servitude and attempts to subvert ethnic distinctiveness and the perception of the Aapravasi Ghat as a representation specifically of Indian indentured memory. This study uses Torabully's concept of Coolitude as a theoretical framework, reading the indentured experience along with the Aapravasi Ghat, as they are presented in Torabully's poetry, as an inaugural space that gave rise to the aesthetics of diasporic hybridity and a humanism of diversity. This study ultimately contends that Torabully's poetry seeks to disturb nationalist discourses that emphasize ethnic distinctiveness related to the indentured experience and the Aapravasi Ghat. Although his poetic engagement involves a reproduction of certain Indo-centric perspectives expressed through references to the kala pani and the fakir figure, which are fundamentally grounded in an Indian historical and cultural realm, Torabully recasts the history of the indentured identity to underscore its overlooked cultural and ethnic multiplicity.

\section{Historical Considerations}

On July 16, 2006, the United Nations Educational, Scientific, and Cultural Organization (UNESCO) inscribed the Aapravasi Ghat as a new site to its World Heritage List (WHL). Located in the Trou Fanfaron coastal region in the capital city of Port Louis, Mauritius, the Aapravasi Ghat is strongly associated with the history of indentured labor. Following the abolition of slavery in the early nineteenth century, plantation owners began seeking out alternative labor forces. They finally resorted to a cheaper source of labor through the system of indentureship, commonly referred to by the British as the Great Experiment, whereby workers signed five-year long contracts which, once expired, allowed them to either repatriate or renew their contract for another five-year period. Indentured laborers in Mauritius were comprised mainly of Indians (452,000),

\footnotetext{
${ }^{1}$ Khal Torabully, Voices from the Aapravasi Ghat: Indentured imaginaries (Port Louis: Aapravasi Ghat Trust Fund, 2013).
} 
Chinese (25,000), Africans (7,630), and Malagasy $(5,000) .^{2}$ That new system, which officially began in 1834 and lasted until the early 1900s, transformed the demographics of Mauritius and led to it becoming a multi-ethnic space that facilitated the global migration of people of various nationalities, including Africans, Malagasy, Chinese, and Indians.

With no known indigenous population, Mauritius has a unique history that continues to inform its national identity politics. Along with Reunion and Rodrigues, Mauritius is part of the Indian Ocean's Mascarene Islands. It remained uninhabited until the arrival of the Dutch in 1602; the Dutch would end up staying on the island until 1658. A second settlement of Dutch immigrants took over the island in 1664, but finally withdrew in 1710 when the French East India Company occupied Mauritius and renamed it Île de France. Eventually in 1767, the French royal administration took possession of the island's affairs. French rule in Mauritius lasted until 1810 when the British defeated the French army and claimed the island as its own. Mauritius remained a British crown colony until its independence in 1968. The island's early history is greatly marked by the system of slavery. Dutch and French settlers brought slaves from different parts of the world to work in construction, deforestation, and agricultural sectors. As the sugar economy in Mauritius expanded, so did the slave population under both French and British rule. After the abolition of African slavery in 1835, British officials and plantation owners engaged in a system of indentureship, which brought thousands of laborers to Mauritius to continue to work on the sugar estates either in Mauritius or overseas in other European colonies across the Atlantic.

Comprised wholly of descendants of immigrants who came to the island in different waves, Mauritius makes for a multicultural nation par excellence. Still, defining a national identity has proven problematic; certain ethnic groups of Mauritians- particularly the dominant Indo-Mauritians who account for approximately 65 percent of the population (48 percent Hindu, 17 percent Muslim) - construct their sense of belonging through an attachment to an external ancestral homeland rather than their island home. Françoise Lionnet, for instance, considers Mauritius a "model' postcolonial state, one that is even being hailed as a superb example of successful mediations of the uncertain relationship between nationhood and ethnic or cultural

\footnotetext{
2 Jean-Louis Miège, Indentured Labour in the Indian Ocean and the Particular Case of Mauritius (Leiden: Center for the History of European Expansion, 1986), 2.
} 
identity." With its racially and ethnically diverse demographic, Mauritius strives towards cultivating a particular national ideology axed on the multicultural politics of "unity in diversity." This paradigm promotes an ideal of coexistence that perceives difference as a point of commonality that brings together the various ethnic identities in Mauritius. Although this particular politics of multiculturality is criticized for cultivating a vision that eschews national unity and a collective sense of belonging to Mauritius, Lionnet is careful to point out that "national unity" does not necessarily mean "uniformity" and that nationalism "is a willed affirmation of solidarity in spite of linguistic, racial or religious differences." " Other scholars, such as Thomas Hylland Eriksen, contend, however, that this model represents "a contradiction in terms." 5 Eriksen contests that "[n]ational unity can be taken to imply loss of distinctiveness (identity), whereas to remain distinctive may seem to preclude national unity."6

Mauritius' national identity politics grounded in interethnic harmony and coexistence was called into question in 1999 when violent riots erupted across the island following the suspicious death of the popular Creole singer, Kaya, in police custody. Although Lionnet sees that tragic event and its resulting social unrest as "the exception that confirms the rule of generally peaceful cohabitation," "7 scholars such as Julia Waters argue that it unveiled underlying interethnic tensions and social class divisions that persistently pervade the seemingly harmonious "model" multicultural nation:

The Kaya riots of 1999- the first serious social unrest to beset Mauritius since independence-dramatically highlighted widespread and longsimmering ethnic and class divisions behind the island's image as a harmonious and prosperous "rainbow nation": divisions that the rhetoric of "unity in diversity" has sought to occlude and that the prevalent, exclusionary practices of communalist, ethnic belonging had arguably helped to exacerbate. ${ }^{8}$

\footnotetext{
${ }^{3}$ Françoise Lionnet, "Créolité in the Indian Ocean: Two models of cultural diversity," Yale French Studies, 82, 1 (1993), 106.

${ }^{4}$ Françoise Lionnet, "Introduction: Mauritius in/and global culture: Politics, literature, visual arts," International Journal of Francophone Studies, 13, 3-4 (2010), 375. Italics in original.

${ }^{5}$ Thomas Hylland Eriksen, "Nationalism, Mauritian style: Cultural unity and ethnic diversity," Comparative Studies in Society and History, 36, 3 (1994), 558.

${ }^{6}$ Ibid.

${ }^{7}$ Lionnet, "Introduction," 397.

${ }^{8}$ Julia Waters, The Mauritian Novel: Fictions of belonging (Liverpool: Liverpool University Press, 2018), 10.
} 
Whether regarded as a social anomaly or "a symptom of a much broader, deeper and entrenched social malaise," the Kaya riots served "as a wake-up call, reigniting debates about the interrelated notions - and lived realities - of nation, community, and belonging in multi-ethnic Mauritius, 30 years after independence." 9 The national and international recognition of the Aapravasi Ghat, discussed later in this paper, amplifies ethnic divisions and further complicates the conceptualization of national unity in Mauritius. Torabully's poetry attempts to bridge those divisions by reinventing new and more nuanced ways of reading cultural identity.

\section{The Aapravasi Ghat and its World Heritage Status}

Throughout its history, the Aapravasi Ghat, established in 1849, saw several transformations and served many functions. During the indentureship period, it was referred to as the Immigration Depot and was used to accommodate the arrival of indentured workers. The site not only received and recorded the indentured laborers before they were sent off to French planters (although the island was under British rule since 1810, the economy remained in the hands of the French plantation owners who owned most of the sugar estates), it was also used to lodge complaints from laborers working on the island. ${ }^{10}$ Even after the end of indenture, immigration and indenturerelated affairs were processed at the site before it gradually fell out of its transactional use in the mid-to-late twentieth century. Aside from its practical purpose during the indentured period, the site served as a hub that facilitated intercultural exchange among people of varying ethnicities and socio-economic backgrounds. However, in the aftermath of Mauritian independence in 1968, it turned into an emblem of Indian indentured servitude and became instrumental in the effort to promote a singular history that emphasized the Indian diaspora as indentured laborers. In popular discourse, the site became known as the Coolie Ghat in the 1970s, and was eventually renamed Aapravasi Ghat in 1987, when it was declared a national monument in Mauritius.

The renaming of the site from Coolie to Aapravasi Ghat (Hindi for immigrants' landing place) is problematic for several reasons and exemplifies the Indo-Mauritians' singular and biased approach to indentured history. ${ }^{11}$ Firstly, it signals a glorified

\footnotetext{
${ }^{9}$ Ibid., $10-11$.

${ }^{10}$ Jayshree Mungur-Medhi, "The reconstitution of Aapravasi Ghat, a Nineteenth-Century immigration depot in the capital city of Port Louis, Mauritius, through archaeology," International Journal of Historical Archaeology, 20, 4 (2016), 784.

${ }^{11}$ The International Council on Monuments and Sites (ICOMOS), one of three advisory bodies that informs the World Heritage committee on cultural heritage, recommended a deferral of the Aapravasi Ghat to the World Heritage List. Along
} 
departure from the pejorative term, coolie, and its association with the supposedly lowly origins of the indentured laborers. Secondly, it calls into question the accuracy of defining the indentured laborers as "immigrants" since many of the laborers had the intention to return to India. Furthermore, its Hindi designation signals the claiming of cultural property by and privileging of one social and ethnic group (Indians) in spite of the fact that indentured laborers, as Torabully points out in his poetry, came from Africa, Madagascar, and China. And, finally, the Hindi name, Aapravasi, implies ethnolinguistic superiority whereby it affords the Hindi language and Hindi speakers a privileged status and overlooks the linguistic diversity of the island's indentured diaspora, many of whom spoke Bhojpuri, Telugu, Tamil, Urdu, and Mandarin. ${ }^{12}$ The change in the site's name can be read as a political and national statement of IndoMauritian hegemony prevalent in Mauritius. It highlights the controversial use of the site as a representation of Indian diasporic historicity, which obscures African, Malagasy, and Chinese laborers from Mauritius' history of indenture.

The acquisition of World Heritage status from UNESCO adds another layer of complexity to critical considerations of the Aapravasi Ghat. Emerging out of the ravages and atrocities of war and conflict, UNESCO, founded on November 16, 1945, committed itself to fostering peace building and security initiatives by promoting collaboration among nations through education, science, and culture. As a specialized agency of the United Nations and successor of the League of Nations' International Committee on Intellectual Cooperation, UNESCO aspires to achieve global progress, development, and support. These foundational utopian ambitions constitute, as critics have noted, both its strengths and weaknesses. ${ }^{13}$ Although inquiries into the internal affairs and the organization's undertakings go beyond the scope of this study, they do help to highlight some complexities that may arise out of inscription in the World Heritage program as it relates to the Aapravasi Ghat. Initially conceived as an

with signaling the need for more research on indentured labor and its impact on the indentured labor diaspora around the world, it suggested that the name of the site be changed from Aapravasi Ghat to Immigration Depot "in order to signal that the place has significance for all immigrants of all creeds" (UNESCO World Heritage List, "The Aapravasi Ghat": https://whc.unesco.org/en/list/1227/ [accessed: 15 July 2019]). However, India's permanent delegate to UNESCO dismissed the concern of missing research, rejected the name change of the Aapravasi Ghat, and called for the Committee to support its immediate inscription. The unyielding support from the Indian delegate, which helped Mauritius acquire its first World Heritage title, emphasizes the strong cultural and political ties to an Indian heritage. (UNESCO, "Convention concerning the protection of the world cultural and natural heritage, World Heritage Committee, Thirtieth Session" (2006), 175: http://whc.unesco.org/archive/2006/whc06-30com-inf19e.pdf, [accessed: 18 February 2021]).

${ }^{12}$ See: Patrick Eisenlohr, Little India: Diaspora, time, and ethnolinguistic belonging in Hindu Mauritius (Berkeley, CA: University of California Press, 2006).

${ }^{13}$ On this particular subject, see, for example: Lynn Meskell, A Future in Ruins: UNESCO, world heritage, and the dream of peace, (Oxford: Oxford University Press, 2018). 
internationally oriented organization set on promoting cultural understanding and peace, UNESCO transitioned over the years into an inter-governmental powerhouse agency in which resource-rich and influential state parties mobilize their cultural capital to disproportionately dominate delegations and decision-making processes. As Lynn Meskell notes, "The overreach of powerful governments has come to permeate all aspects of [UNESCO's] functioning. This is reflected in the workings of many of its high-profile programs, including World Heritage - the program that seeks to identify, protect, and preserve outstanding cultural and natural heritage sites around the world." 14 Certainly, it would be unfair and misguided to completely dismiss UNESCO and its World Heritage program's accomplishments in fostering worldwide interest in heritage preservation, and its capacity to hold member states accountable to honor their commitment to conserve global patrimony. However, the process involved in the actual application and realization of World Heritage classification and its implications for local communities problematizes the conservation project and its international aspirations. The privileging of temporary technical assistance over the program's initial motivation to expand world peace and cultural understanding and tolerance through active and sustainable methods adds to the contentious nature of its preservation efforts. ${ }^{15}$

On the one hand, the World Heritage program bestows ancient and historic sites like the Aapravasi Ghat with international prestige, drives cultural tourism, builds local pride, and encourages foreign investment and development funds. On the other hand, the influential power of typically western nations in determining World Heritage status raises questions about sovereignty and reinforces Euro-centric power structures that discreetly endorse a contemporary iteration of a colonial civilizing mission masked as heritage preservation. UNESCO then becomes the brand name under which these institutional and international entities determine what it means to "make" heritage. 16 Likewise, such a program that places great emphasis on monumentality, static lists, and classification diminishes the importance of exploring the dynamism of heritage and the multilayered facets of places and their histories. Moreover, heritage branding lays broad, yet strong, claims on history and national territory. It both recognizes and privileges one

\footnotetext{
${ }^{14}$ Meskell, A Future in Ruins, xvii.

${ }^{15}$ In 1994, the World Heritage Committee adopted a Global Strategy initiative that aimed to expand and diversify the World Heritage list by emphasizing links, migration, and cultural fusion, as well as acknowledging sites associated with slavery and indentured labor. For more information on this topic as it relates to heritage properties in the Indian Ocean world, see, for example: Christoph Brumann, "Global linkages, connectivity and the Indian Ocean in the UNESCO World Heritage arena," in Travelling Pasts: The politics of cultural heritage in the Indian Ocean, eds. Burkhard Schnepel and Tansen Sen (Leiden: Brill, 2019), 21-38.

${ }^{16}$ David Berliner and Chiara Bortolotto, “Introduction: Le monde selon l’Unesco,” Gradhiva, 18, (2013), 3.
} 
history, people, and culture, contributing, in some cases, to the program's complicity in exacerbating racial, socio-economic, ethnic, and cultural tensions among local communities.

In the context of Mauritius, the listing of the Aapravasi Ghat as an internationally recognized site enshrines the experience of the Indian diaspora and stresses-perhaps even legitimizes-Indo-Mauritian political and economic hegemony over other more ethnically marginalized groups in Mauritius, including the Afro-Mauritian or Creole community. UNESCO's World Heritage List website describes the Aapravasi Ghat as a site where "almost half a million indentured labourers arrived from India at Aapravasi Ghat to work in the sugar plantations of Mauritius, or to be transferred to Reunion Island, Australia, southern and eastern Africa, or the Caribbean."17 This description contributes to hegemony-making practices and engages in the process of selective omission - which, as I will explain further, Torabully undoes through his revisionist poetry - that excludes from official archival narratives the various nations and peoples who interacted with the site either as indentured laborers or travelers since its inception. Moreover, this inscription cultivates a divisive politics that emphasizes diasporic dissimilarity and concretizes values and practices hailed from ancestral histories and native lands.

It was not until 2008, two years after the Aapravasi Ghat was added to the World Heritage List, that Mauritian officials nominated Le Morne Cultural Landscape, redolent of slavery and the Afro-Mauritian diaspora, for World Heritage status. Located in the southwest of Mauritius, Le Morne was a refuge for runaway slaves in the eighteenth and nineteenth centuries. Likewise, dedicating two different national holidays to commemorate the abolition of African slavery (February 1) and the beginning of Indian indenture (November 2) underscores further the exclusivist approach to diasporic differences that assigns an ostensibly equal but separate positioning for each social group in the national geography and landscape of Mauritius. As Candice Lowe Swift points out in her article, "Privileging the Diaspora in Mauritius: Making World Heritage for a Multicultural Nation," this framework, nurtured by UNESCO's heritage-making practices, risks silencing overlapping pasts "in favor of exclusive and homogenized diasporic histories and contemporary identities." 18 Similarly, these practices

\footnotetext{
${ }^{17}$ UNESCO World Heritage List, "The Aapravasi Ghat." Italics added.

${ }^{18}$ Candice Lowe Swift, "Privileging the diaspora in Mauritius: Making world heritage for a multicultural nation," Diaspora, 16, 3 (2016), 315.
} 
"differentiate, essentialize, and rank diasporas and their descendants."19 Torabully, however, engages with the Aapravasi Ghat's World Heritage status through a more dynamic and humanistic perspective. According to Torabully, the fact that indentured laborers came from various places other than India positions the Aapravasi Ghat as a site of hybridity that generates heightened nuanced discussions and spotlights the human dimension of approaches to cultural identity and global policy. In fact, it was Torabully who recommended to the Head of the Intercultural Division of UNESCO, Ali Moussa Iyé, that Le Morne be added to the World Heritage List. ${ }^{20}$ Torabully seems less concerned about competing narratives of history and more interested in "articulating and not opposing specificities of Mauritians." 21 By connecting the Aapravasi Ghat and Le Morne and, by extension, indentureship and slavery, Torabully develops a notion of humanism of diversity where he constructs a "hybrid imaginary of articulating these two paradigms, without impoverishing them, without negating their specificities, but articulating both to bring a sense of awareness that both episodes negated humanity and bore major meanings to nation-building in Mauritius." 22

\section{Torabully's CoOlitude}

It is out of this tension that Torabully writes Voices from the Aapravasi Ghat: Indentured Imaginaries, in which he foregrounds his concept of Coolitude to present a new perspective on indentured labor and multiculturalism. Developed in the 1990s, Coolitude emerged as a response to former critical expressions of postcolonial cultural identity paradigms. These cultural models privileged Afro-centric discourses and eclipsed the indentured experience from their discussions. The term Coolitude shares obvious similarities with Négritude, an idea which Aimé Césaire, Léon Gontran Damas, and Léopold Sédar Senghor introduced in the 1930s. Négritude advocated for a revalorization of the term nègre and a celebration of black identity, as elaborated in Césaire's long prose poem Cahier d'un retour au pays natal (1939). Though inspired by Négritude, Coolitude, as Torabully reveals, is not, "Négritude à l'indienne" or the “"Indian alter ego' of Négritude." 23 In fact, Coolitude was first introduced in 1992 in

\footnotetext{
${ }^{19}$ Ibid., 291.

${ }^{20}$ Khal Torabully, "The Aapravasi Ghat: A matricial site," Africultures: Les mondes en relation (2009): http://africultures.com/the-aapravasi-ghat-a-matricial-site-9009/ [accessed: 24 July 2019].

${ }^{21}$ Ibid. Italics in original.

22 Ibid.

${ }^{23}$ Marina Carter and Khal Torabully, Coolitude: An anthology of the Indian labour diaspora (London: Anthem South Asian Studies, 2003), 144, 152.
} 
Torabully's work of poetry entitled Cale d'étoiles, Coolitude, and was more fully theorized in 2002 in Coolitude: An Anthology of the Indian Labour Diaspora. The neologism derives from the term "coolie," which in popular discourse has derogatory connotations and can be used as a racial slur to refer to persons of Asian-especially Indian-descent. Accurately defining and contextualizing this term, therefore, is important to understanding Torabully's usage and appropriation of it. The English term, "coolie" stems from the Tamil küli meaning payment for occasional menial work, and the Gujarati Kuli, which refers to a person from the Kuli tribe whose members were often described as "thieves, robbers, and plunderers, as degenerate and inferior." 24 Evidently, as Jan Breman and E. Valentine Daniel point out, the English "coolie" merges the Kuli, as a person, in all its derogatory characterizations, with the payment of $k \bar{u} l i$ to construct the coolie whose relationship to labor production reinforced above all the usage of the term. ${ }^{25}$

Eric Hayot, in his book chapter entitled, "Coolie," underscores this socially constructed connection and highlights that historically coolie did not refer to any particular person, but "a type of work, or rather, an interface between personhood and work, mediated by race, that affected the global history of labor from the seventeenth to the twentieth centuries." ${ }^{26}$ According to Hayot, although this term designated a certain class of common laborers in India as early as the sixteenth century, it did not refer to any particular group of people called "coolies." Rather, he asserts, "Chinese men who traveled to the Americas, or Indians who traveled to the ports in the Caribbean or the Indian Ocean, became coolies the moment they set foot on the boats that ran the transpacific trade in Asiatic labor." ${ }^{27}$ If the coolie did, indeed, exist, Hayot argues, it only existed as the result of structural and economic factors: "Though we can say that certain people have historically been called or have called themselves "coolies," we can also say that the "coolie" has never really existed. Or if it has existed, it has only done so as a socio-cultural concept whose various dimensions - historical, economic, racial, political, syntactic - make up a complex that could not have been, and were never, embodied in a single person or group of people." ${ }^{28}$ As a socially constructed category for indentured labor, which became imbued with offensive and negative meaning and

\footnotetext{
${ }^{24}$ Lydia Potts, The World Labour Market: A history of migration (London: Zed Books, 1990), quoted in: Jan Breman and E. Valentine Daniel, “Conclusion: The making of a coolie," The Journal of Peasant Studies, 19, 3-4 (1992), 269.

${ }^{25}$ Breman and Daniel, "Conclusion," 269.

${ }^{26}$ Eric Hayot, "Coolie," in The Routledge Companion to Asian American and Pacific Islander Literature, ed. Rachel C. Lee (New York: Routledge, 2014), 81.

${ }^{27}$ Ibid., 82. Italics in original.

${ }^{28}$ Ibid., 81.
} 
deployed as a pejorative descriptor, the term coolie strips the indentured laborer off their dignity and humanity. However, the semantic shift over the course of history underscores the coolie as an ambivalent, unstable concept and "multiplex identity," 29 on which Torabully capitalizes in his Coolitude poetics.

By engaging this term through the poetics of Coolitude, Torabully re-ascribes value to it by honoring the memory and exalting the condition of the indentured laborer. He expands its definition, arguing that the coolie "symbolizes, in its broader definition, the possibility of building a composite identity to ease the pain and enrich culturally the lands in which he/she settled." ${ }^{30}$ Indeed, the coolie included people of different religions (Hindus, Muslims, Christians) and ethnicities, which negates its association with any one particular Indian group. Thus, for Torabully, the coolie identity was "not ethnical in its core meaning, but judicial," because it signified labor with a five-year contract. ${ }^{31}$ Although powerful and creative, Torabully's reframing of the term coolie is not devoid of its oversights and inherent contradictions. By reading the coolie identity as merely a "judicial" identity, Torabully overlooks the entire biopolitics behind the racially pejorative label affixed to the indentured laborers. It also does not take into consideration the colonial power dynamic at play in the emergence and sustained usage of this term. It did not constitute an identity that gave the laborers any agency in its articulation and finds limited response in postnational narratives.

In addition to imbuing its definition with new connotations of plurality, Torabully argues that the term coolie also refers to voyagers who set out on a journey to unknown places to seek out a better future: "In saying coolie, I am also speaking of every sailor without / A ship's register, every man who has gone towards the horizon / Of his dreams, whatever the ship he boarded or had to board." 32 By reconstructing and extending the coolie identity within a global context, he takes it out of its historical confinement, and intersects the past with the present and future. Coolitude thus operates within a framework of recuperation, plurality, and cultural exchange, yet romanticizes ancestral links and overplays the indentured laborers' social and political authority in the system of indenture.

\footnotetext{
${ }^{29}$ Breman and Daniel, "Conclusion," 268.

${ }^{30}$ Carter and Torabully, Coolitude, 144.

${ }^{31}$ Torabully "The Aapravasi Ghat: A matricial site."

${ }^{32}$ Original text is in French. Unless otherwise noted, all translations are mine. Khal Torabully, Cale d'étoiles: Coolitude (La Réunion: Azalées Editions, 1992), 89.
} 
Torabully emphasizes that Coolitude resists essentialisms and fixities in the construction of the indentured migrant's identity. It displaces India ${ }^{33}$ and other ancestral lands as the "Ultimate Referent" or core of that identity and instead considers it as a point of departure. ${ }^{34}$ In this sense, it surpasses Indianité, a concept developed and promoted by the Guadeloupean writer and politician Ernest Moutoussamy, which dwells on the imaginary return to an original Indian memory. Coolitude returns to the transoceanic voyage, which, for Torabully, can be both traumatic and regenerative. The sea passage becomes symbolic of a fundamental detachment from the motherland and atavistic cultural values. The resulting displacement, both physical and metaphorical, then gives way to the creation of a dynamic and complex diasporic identity that is ever evolving and perpetually shaped by a plurality of surrounding cultures. In this regard, Coolitude aligns itself closely with Édouard Glissant's concept of créolisation, which approaches identity formation and its relation to diversity as an unending process with unpredictable results. ${ }^{35}$ Torabully uses the image of the coral to articulate the plural identity that is emblematic of Coolitude. With its rhizomatic forms and diverse colors, shapes, and textures, the coral symbolizes "fluidity of relationships and influences." ${ }^{36}$ In this sense, Coolitude mirrors what Iain Walker refers to as "diaspora for others," which extends diasporic "interactions to intra-diasporic relationships, allowing for diasporic practice to structure relationships between different places in diaspora usually but without necessarily, involving the homeland." 37

Given Coolitude's aim to recuperate the lost indentured memory, which has been obscured by colonial history and expressions of postcoloniality, the Aapravasi Ghat plays a significant role in the recollection process. It is an historical monument and the only site in the world that officially recognizes and preserves the history and memory of the indentured labor system rather than one particular ethnic group. In this regard, the Aapravasi Ghat manifests itself into what I call a realm of indentured memory. First established by the French historian, Pierre Nora, the concept of lieux de mémoire, or realms of memory, refers to embodiments of memorial consciousness where "memory

\footnotetext{
${ }^{33}$ Although indentured migrants came from several other countries, as mentioned elsewhere in this paper, Torabully references India in his initial conceptualization of Coolitude, likely because the majority of indentured laborers came from India. However, in his poetry, as I will highlight later, "India" becomes a stand-in for ancestral lands. Torabully remains aware of the other nations and its people who were involved in the indentured experience and beyond, which help shape his Coolitude project and its emphasis on what he calls humanism of diversity.

${ }^{34}$ Carter and Torabully, Coolitude, 147.

${ }^{35}$ Édouard Glissant, Poétique de la Relation (Paris: Gallimard, 1990), 40.

${ }^{36}$ Carter and Torabully, Coolitude, 152.

${ }^{37}$ Iain Walker, "The Hadrami diaspora: A “diaspora for others" in the Indian Ocean," Journal of Indian Ocean World Studies, 4, 2 (2021), 114-36.
} 
crystallizes and secretes itself." 38 Recent revisions that consider the concept of lieux de mémoire through a postcolonial lens are articulated in the edited volume, Postcolonial Realms of Memory: Sites and Symbols in Modern France. The editors, Etienne Achille, Charles Forsdick, and Lydie Moudileno, address the theoretical gap in Nora's lieux de mémoire that largely excludes the legacy of colonialism and its postcolonial aftermath in shaping national memory using their concept of postcolonial realms of memory: "Postcolonial realms of memory, as we (re)conceptualize them, are therefore defined here as spatial/functional or immaterial sites, potentially subject to abstraction and imbued with a symbolic aura that, in the context of the French everyday, refers to more or less tangible memory traces linked to the colonial." ${ }^{39}$ As a realm of memory that crystallizes traces of indentureship, the Aapravasi Ghat extends and diversifies Achille, Forsdick, and Moudileno's concept of postcolonial realms of memory to draw attention to another layer of French imperial rule beyond slavery and colonization. The Aapravasi Ghat embodies a materialization of indentured memory and history that links the past with the present and future. In accordance with the characteristics of Nora's lieux de mémoire, the Aapravasi Ghat is at once material (through its physical structure), symbolic, and functional (as preservation of a shared past). It breaks temporal continuity and returns to a point in history that denies historical amnesia and monumentalizes an experience that affected the lives of thousands of indentured migrants of various backgrounds. In this sense, the Aapravasi Ghat reconstitutes new meaning and situates itself as a space that facilitated postcolonial encounters.

\section{REVISING INDENTURED DIASPORIC IMAGINARIES}

Torabully's Voices from the Aapravasi Ghat: Indentured Imaginaries, written in English, is divided into Book I (which is further subdivided into Voice I: The Rape of the Flock and Voice II), and Book II: Voices from Indenture. Book I opens with a depiction of life at the Aapravasi Ghat. By staging the opening scene at the depot rather than the indentured laborers' native land, the poet immediately draws attention to what he has termed elsewhere the coupure fondamentale, or severing of ties with the laborers' birthplace, occasioned by the transoceanic voyage. ${ }^{40}$ Moreover, the fact that the opening scene dismisses the return to India and instead focuses on the arrival at the Aapravasi

\footnotetext{
${ }^{38}$ Pierre Nora, "Between memory and history: Les lieux de mémoire," Representations, 26 (1989), 7.

${ }^{39}$ Etienne Achille, Charles Forsdick, and Lydie Moudileno, Postcolonial Realms of Memory: Sites and symbols in modern France (Liverpool: Liverpool University Press, 2020), 9.

${ }^{40}$ Carter and Torabully, Coolitude, 159.
} 
Ghat implies a displacement of the motherland as the central point of the migrants' universe and returns to a nodal point of their indentured experience, contributing to the construction of a new, complex, and dynamic identity.

Coolitude's agenda to recuperate coolie history and memory inevitably turns to the trauma, displacement, abuses, and victimization that define that diasporic experience. In the opening lines of his poetry, Torabully introduces an unnamed indentured female who is represented in ambivalent terms: "Here is my deposed life / Prospected vagrant / prospective migrant." ${ }^{41}$ The play on the word "deposed" implies both the persona's testimony about her life at the depot and the associated displacement of the indentured experience. Her depiction as a "vagrant" takes on a double meaning that reinforces her uprooted existence and suggests her condemnation as a disreputable social derelict. It also hints at the fact that many indentured workers were denounced as vagrants because they deserted their work. Torabully, however, reads that vagrancy as a form of revolt and resistance, similar to marronage during slavery. ${ }^{42}$ The poet continues to highlight the migrant's predicament, indicating her treatment as human cargo: "I was dispossessed and processed/ As a manwomanchild after slaveslappedslammed." 43 This disregard is further emphasized by the visual lumping together of the words man, woman, and child into one expression, highlighting her depersonalization as a subject of the indentureship system that compromised her dignity, individuality, and humanity. The migrants' ill treatment is also reflected in their poor living conditions, which resulted in the spread of disease and left them vulnerable to harsh elements and severe weather conditions, ultimately leading to death: "dying now in ghat and depots / in hold / en-route from colonies to cholera / from typhoid to typhoon, / from dysentery to despair, / from measles to muscles / from venerable to venereal diseases." 44 The system of indentured servitude, then, presented itself as a life-threatening experience in which the well-being of the indentured servants was not prioritized.

In this poetic work, Torabully also reveals the deceptive recruitment methods used to lure individuals into indenture. The text indicates that "Like them as poor rose I arose / spitting on this conned country / saying it is so ugly / so ugly like our migrant's journey," 45 and later on "They were promised milk and honey / And they say the taste is

\footnotetext{
${ }^{41}$ Torabully, Voices from the Aapravasi Ghat, 2.

${ }^{42}$ Carter and Torabuly, Coolitude, 161.

43 Torabully, Voices from the Aapravasi Ghat, 2.

${ }^{44}$ Ibid., 20.

${ }^{45}$ Ibid., 2
} 
bitter like sugar;"46 "Remember famine and sepoy revolt? / So many came not kidnapped but decoyed;" "Come to the cane, gold is under the stones." Coolitude: An Anthology of the Indian Labour Diaspora, Carter and Torabully highlight several cases of migrants who were under the false assumption that they were being employed by the East India Company, which they believed was the government of India. ${ }^{49}$ Indentured laborers were deliberately misled by the duplicitous rhetoric and false promises that authorities in India and elsewhere used to entice potential recruits. Torabully emphasizes that deception stylistically through contrasts whereby he opposes the promises made ("milk and honey") with the reality of the system of indentured servitude ("bitter like sugar") in which laborers were required to toil on the sugarcane plantation and subjected to dreadful experiences.

The newly arrived laborers entered into a world where the social structure was already established. They were considered society's Other and were victimized and stigmatized. They were ostracized as "paria" 50 and their existence is described as "foul," 51 "filthy and dirty." 52 The poet uses an internal rhyme "Immorality is next to coolie" to suggest the negative perception of the laborers as unclean and immoral. ${ }^{53}$ As part of his recovery project, Torabully veers away from romanticized images of the indentured migrant, often mistaken as a uniquely Indian identity, as well as from nostalgic stories of a lost homeland. Instead, he offers a counter poetics, both semantically and stylistically, that underscores the alienation and displacement underpinning the indentured experience.

In recuperating the memory and history of indenture, Torabully also recognizes the possibilities that the diasporic experience afforded in terms of the construction of a complex and dynamic identity. Two-thirds of this work comprise Book II: Voices from Indenture: Coral Imaginaries: The Fakir's Aesthetics. The evident shift from the singular "Voice," at the beginning of this work of poetry, to the plural "Voices" in Book II seems to be reflective of the multiple ethnicities that constituted the indentured identity. In this collection, the poet makes reference to the diverse ethnic backgrounds of the indentured laborers: "they said names of my alienness / Indianness africanness chineseness

\footnotetext{
${ }^{46}$ Ibid., 22.

${ }^{47}$ Ibid., 24.

${ }^{48}$ Ibid., 30.

${ }^{49}$ Carter and Torabully, Coolitude, 26.

${ }^{50}$ Torabully, Voices from the Aapravasi Ghat, 6.

${ }^{51}$ Ibid., 16.

${ }^{52}$ Ibid., 18.

${ }^{53}$ Ibid., 17.
} 
normandiness / malagasyness ethiopianness and transnational dizziness / And others named more from unknown borders." 54 The added suffix "ness" to these various nationalities, together with the absence of punctuation, disperses stoic visions of national identity and instead qualifies characteristic states of being that have experienced some form of transnationality. Torabully also enhances his text with archival images portraying Mozambiquan ${ }^{55}$ and Chinese ${ }^{56}$ indentured laborers who arrived in Mauritius in 1856 and 1870, respectively. These documented images reinforce the fact that indentured laborers included people from places other than India, including Africa, Madagascar, and China. This unsettling of indentured history additionally avoids the projection of a singular history that connects indenture with persons of Indian origin. Torabully's poetry, therefore, undoes selective silencing and recollection and sheds light on overlapping histories of the multi-ethnic population passing through the Aapravasi Ghat.

As part of his counter poetics, Torabully shapes an inclusive approach and provides a more nuanced perspective to Otherness that unveils the diversity in indenture, which he grounds in historical facts. To develop the notion of diversity as a founding element of indenture, Torabully reexamines the master narrative that maps the indentured identity as one that is exclusively associated with an Indian diaspora and negates the singularity of that identity. Within the context of Indian indenture itself, diversity prevailed, since laborers came from a myriad of places in India, spoke various dialects, and belonged to different castes. They also differed in terms of their religion, social conditions, gender, and age. This mosaic identity is revealed in Torabully's landmark text Cale d'Étoiles Coolitude: "Define me, I beg you/ What is a coolie? / [...]I am Lascar, Malabar, / Madras tamarind from the bazaar / Telegu if that is my liking. / Cruel mother Marathi or Chamar / Whatever, I am Indian negro, / Guinea pig, from Port Louis to Port of Spain, /To replace mighty slaves of Zanzibar." ${ }^{\prime 57}$ By underscoring the plural origins of the Indian indentured identity, Torabully undoes the notion that this identity was ever based on one homogenous Indian identity - an idea cultivated as a major part of the Indian diasporic imaginary. Moreover, Torabully goes even further here and invokes the multiplicities of oceanic trajectories (Port of Spain referring to the

\footnotetext{
54 Torabully, Voices from the Aapravasi Ghat, 13.

${ }^{55}$ Khal Torabully, Cale d'étoiles: Coolitude (La Réunion: Azalées Editions, 1992), 27.

56 Ibid., 40.

${ }^{57}$ Khal Torabully, Cale d'étoiles, 25.
} 
indentured laborers' travels to Trinidad in the Caribbean), ethnic (Marathi) and caste (chamar) differences.

Torabully stresses the open possibilities of the indentured experience in his poetry. From the beginning of this collection, the poet hints at the desire for newer and refreshed perspectives that reformulate the history and memory of the indentured experience: "No dark waters to drink / but clear waters to think." ${ }^{58}$ Furthermore, the text reveals: "India bhaya / please be preserved / like achar and pickled mangoes / so be Africa China and batana. / But I want a new sea / to recast the voyage across kala pani / I tried to nullify $\sin$ and to purify pee."59 The poet's reference to "dark waters" immediately conjures up the taboo of the kala pani. This taboo refers to a Brahminical perspective regarding caste and overseas travels, that governed the lives of upperechelon castes, members of which rarely became indentured laborers. Transoceanic travels across the kala pani signified a cultural transgression and national betrayal, which led to a loss of caste after departure and social ostracization upon return to India. Those who chose to cross the kala pani were automatically compromising their belief system and cultural purity. By framing the indentured experience within a specifically orthodox upper-caste Hindu paradigm, Torabully contradicts his attempts to articulate a shared indentured experience that disrupts ethnic, religious, and caste distinctiveness to give way to possibilities of cultural openness and creolization. Moreover, as Mathieu Claveyrolas indicates, this contextualization that structures the indentured experience from a caste perspective, misconstrues the "Indian peasants' concerns with the intellectual and ritual constraints practised by the elites of the period." 60

Nonetheless, as Marina Carter suggests with her Across the Kalapani: The Bihari Presence in Mauritius, considerations of the kala pani concept still involve an exploration of the transoceanic crossing as a traumatic event and relate the indentured experience to the Middle Passage and slavery ${ }^{61}$ Departure from India, which signified a disruption in caste and kinship systems, and travel across the kala pani would have exacerbated the cultural trauma and harsh conditions of the indentured experience. But this association between the Middle Passage and the kala pani and the systems of slavery and indentureship once more misleadingly connects the slave experience to a

\footnotetext{
${ }^{58}$ Torabully, Voices from the Aapravasi Ghat, 4.

${ }^{59}$ Ibid., 17-18.

${ }^{60}$ Mathieu Claveyrolas, "The 'land of the Vaish'? Caste structure and ideology in Mauritius," South Asia Multidisciplinary Academic Journal (2015), 7.

${ }^{61}$ Marina Carter, Across the Kalapani: The Bihari presence in Mauritius (Port-Louis: Centre for Research on Indian Ocean Studies, 2000).
} 
specific orthodox upper-caste Hindu experience. On the other hand, it gives way to the possibility of developing new perspectives of cultural openness rooted in a creolized future. Indeed, narratives of indentureship envisage the transoceanic crossing as a rite of passage that not only entails separation, liminality, and aggregation but also a re-birth that foregrounds solidarity through shared experiences. ${ }^{62}$ This re-birth, for Torabully, also implies openness to cultural difference.

Returning to the poetic text cited above, Torabully seeks to replace the "dark waters," symbolic of the journey and the old formulations of the indentured imaginary, with "clear waters," insinuating renewed efforts to conceptualize the indentured existence. By calling for the preservation of India along with Africa, China, and "batana" (bangle), which connotes solidity and enclosed circularity, Torabully relays the static nature of these ancestral lands and undermines their significance to diasporic imaginaries. He aspires to a shift in diasporic social consciousness whereby the indentured diaspora does not simply ingest, metaphorically speaking, and adheres to previous constructions of a diasporic identity that dwells on nostalgic sentiments of a lost homeland ("dark waters to drink"). Instead he calls for the diaspora to mobilize its agency to call into question and reflect critically and creatively ("clear waters to think") on its engagement with its past.

The poet is no longer interested in cultural preservation; he searches for a new sea to reimagine the voyage and its symbolic significance to the past, present, and future of the indentured experience: "Life on the kala pani/Can also be the voyage to ultimate reality." ${ }^{2}$. The poet's use of the conjunction "also" suggests that he is not denying the pain and suffering associated with exile and displacement resulting from indentureship. Instead, he is more interested in seeking out potentially positive aspects that can emerge from that traumatic experience. He urges, "Keep crossing jahaji / Keep steering dear coolie / Life is a ceaseless journey / From your broken dream to a new day. [...] Keep sailing to Mirish Desh and Tapu Calen [...] Keep your feet on the waves and the furrows / [...] Keep crossing the kala pani / Pariah fakir sadhu or noble coolie." 64 The repetition of the verb "keep" in its imperative form followed by the gerund form of the subsequent verbs suggests that the poet is persuasively commanding the indentured diasporic community to endure and look forward to new realms of possibilities despite

\footnotetext{
${ }^{62}$ Mathieu Claveyrolas, "'Indo-Mauritians' and the Indian Ocean: Literacy accounts and anthropological readings," Journal of the Indian Ocean Region, 13, 2 (2017), 182.

${ }^{63}$ Torabully, Voices from the Aapravasi Ghat, 50.

${ }^{64}$ Ibid., 50-51.
} 
past traumas and setbacks. Likewise, his usage of marine lexicon (crossing, steering, sailing, waves) relates to the symbolic fluidity and forward movement at play in his concept of Coolitude.

On disembarking the ships, indentured laborers entered into Mauritius by climbing a flight of stairs at the Aapravasi Ghat, which have become symbolic of their entry into the island: "After thirteen steps to go to the Ghat, / I said farewell to the waves in me, / but never to the ship of the Kala pani...." 65 The corporeal movement of ascending communicates the pivotal spatio-temporal displacement and emotional detachment through which the persona is able to let go of the uneasy feelings ("waves") provoked by exile and displacement. The persisting memory of the ship, which itself stands in for the transoceanic crossing and movement, once more alludes to the poet's intention to re-engage the marine space in a new approach to diasporic indentured identity that privileges openness and continuity, as suggested by the ellipsis at the end of the above verse. Moreover, the staircase that led to the Ghat symbolizes an interstitial space between the sea and land. It provides a figurative bridge that metaphorically connects the laborers across cultural, geographic, religious, and ethnic boundaries. It is here that the Aapravasi Ghat transforms into a matrix site. Torabully indicates:

[T] he Ghat is matricial in its essence. This open attitude entails that one can view Mauritian History, and modern migrational History in a more diverse, variegated way, fraught with a post-modern, post-structuralist conception, more tuned to comprehend the complexity of multicultural and transcultural processes at work in modern hybrid societies. It offers a humane foundation for the exploration of our History. The Ghat highlights this reality and holds further promises to me." 66

If understood as a realm of indentured memory where diversity persisted, the Aapravasi Ghat articulates and embodies an indentured memory that engages with historical subtleties, multiple layers of meanings, and holistic considerations. It becomes a didactic site that brings awareness to the hybridity that defined indentured history, catapulting Torabully's notion of humanism in diversity: "[The fact that the first set of slaves in Mauritius were of South Asian descent along with the plural origins of indentured laborers] should be enough to make us read History from a more humane angle, warding

\footnotetext{
${ }^{65}$ Ibid., 44.

${ }^{66}$ Torabully, "The Aapravasi Ghat: A matricial site."
} 
off exclusive, sometimes unjustified, views construed from major human tragedies that have framed our coralian, complex, variegated societies. $" 67$

To explore the complex multiplicity of identities embodied in Coolitude, Torabully presents an ethereal and mystical figure, the fakir. Derived from the Arabic term $f a q r$, meaning poverty, fakir or fukeer (the Anglicized spelling of the Arabic faqī $r$ ) has come to refer to an Indian social type. Winston Churchill notoriously called Mahatma Gandhi a "seditious...fakir of a type well known in the East." Although meant as an insult gleaned from long-standing, disparaging western conceptions of South Asian ascetics, Gandhi regarded Churchill's remark as a compliment, believing he was unworthy of the title: "I have been long trying to be a 'Fakir' and that naked-a more difficult task. I, therefore, regard the expression as a compliment, though unintended." ${ }^{69}$ For both men, fakir conjured up very different meanings. As Timothy Dobe highlights, "The term is unsettled between the sedition of Churchill's suspicions and the naked striving after religious perfection invoked by his Indian opponent." 70 Throughout its history, the term has been imbued with a plurality of meanings that have shaped its understanding.

Despite the fact that mendicant Sufis first introduced the term fakir to India, it was eventually used to refer to "holy men of Muslim, Hindu, or indeterminate religious affiliation." "71 Although this semantic change conceivably stems from the indiscriminate and erroneous colonial application of the term for Indian holy men and their followers of non-Muslim origin, its indigenous usage has been interpreted by scholars such as Dobe as a reflection of "rich and fluid identities, which cannot be assigned to one religion.""72 Dobe contends further that these usages of the term "... are grounded in shared religious practices, symbols, rituals, and terms in precolonial Punjab, sharings that simultaneously enabled novel combinations and claims to authority." 73 Asceticism, renunciation, and mendicancy characterized the fakir's existence, which led to their social isolation among Indians and non-Indians alike. They constituted a less respectable class of unruly drugusers who were seen as India's harlequins. In this respect, the fakir and his vulgar

\footnotetext{
${ }^{67}$ Ibid.

${ }^{68}$ Mahatma Gandhi, The Essential Gandhi: An anthology of his writings on his life, work, and ideas, ed. Louis Fischer (New York: Vintage Books, 2002), 450.

69 Ibid., 573.

${ }^{70}$ Timothy S. Dobe, Hindu Christian Faqir: Modern monks, global Christianity, and Indian sainthood (New York: Oxford University Press, 2015), 12.

${ }^{71}$ Nile Green, "The faqir and the subalterns: Mapping the holy man in colonial South Asia," Journal of Asian History 41, 1 (2007), 60 .

${ }^{72}$ Ibid., 14.

${ }^{73}$ Ibid.
} 
comportment represented, as Green points out, "the ultimate affront to Britain's civilizing mission." ${ }^{14}$ British colonial authorities casted the fakir as a social anomaly and radical public nuisance, as reflected in Churchill's comments. However, when considered as divinely inspired, the fakir's buffoonery is rendered sacred: “...[his] ecstasy or madness provided him with a sanctified or 'clown's license' that he was able to deftly exploit..."75 Within this frame as a sanctified, insane buffoon, the fakir gains both a social notoriety and authority that subvert colonial order and challenge the colonialist's narrative of absolute power. Along with his miracle-granting powers, the fakir garners a cult-like following, which amplifies his social influence in colonial Indian society.

This influence, however, is not unidimensional. As Green reveals, the fakir's social identity and role are inevitably shaped by his followers, which render him not "as a fixed social type, but a changing figure adapting a flexible repertoire to the needs of his audience." ${ }^{76}$ As his following expands, so does his cultic persona to "accommodate the norms projected onto him by his diversifying constituency."77 To articulate this pluri-layered existence, Green uses the term polyvestiary to refer to the fakir: "Various groups of followers symbolically 'clothe' them in ways reflecting the group's own religious tradition." 78 Moreover, polyvestiary implies "a process of the 'dressing up' of the holy man," which explains "the multiple identities that such holy men often acquire." 79 The fakir then becomes an embodiment of a plural identity that is openended, fluid, and constantly evolving, determined to challenge the status quo and go beyond his human condition.

In Voices from the Aapravasi Ghat: Indentured Imaginaries, the reader is introduced to the fakir in Book II who, in his own poetic voice, describes himself as follows:

I am the man of imbalance and plasticity.

In me the gestures of the ocean are free.

I may stand on my elbow or on my knee.

Whatever is in the world must flow easily.

\footnotetext{
${ }^{74}$ Nile Green, "Jack Sepoy and the Dervishes: Islam and the Indian soldier in Princely India," Journal of the Royal Asiatic Society, 18, 1 (2008), 35.

${ }^{75}$ Ibid.

${ }^{76}$ Green, "The faqir and the subalterns," 58.

${ }^{77}$ Ibid., 59.

${ }^{78}$ Ibid.

${ }^{79}$ Ibid., 59-60.
} 


\section{$[\ldots]$}

My network is beyond boundaries and imaginaries.

$[\ldots]$

I am the opacity of people who are conversant

With the idioms of coral and currents. ${ }^{80}$

This passage relays the asymmetrical and malleable nature of the fakir's existence, which is predicated on dynamism and unpredictability. It also reveals the fakir as a contortionist who achieves corporeal flexibility and fluidity through negotiation between balance and imbalance. The reference to a "network beyond boundaries and imaginaries" presents the fakir as a polyvestiary saint, as defined by Green, whose multi-layered identity and palimpsestic reality amplify his opacity as he is constantly being refashioned by his interactions with diverse groups of people and places.

Further to this depiction, Torabully presents the fakir as a fragmented being:

\section{A fakir lives from fragments}

Fragments of clothes and food

Fragments of status and nationhood

Bits and tatters in his laments

But totality is the real sap

In which he finds honey

As he knows how subaltern reality

Can be dry like a prison tap.

With ambiguity I make distortions

With familiarity I make revolutions.

I seize the kala pani to see new visions. I decontextualize set

representations. I am the coral's vivid circumvolutions. ${ }^{81}$

This fragmented reality recalls Derek Walcott's Nobel Laureate lecture "The Antilles: Fragments of Epic Memory," in which he says, "Break a vase, and the love that reassembles the fragments is stronger than that love which took its symmetry for granted

\footnotetext{
${ }^{80}$ Torabully, Voices from the Aapravasi Ghat, 49.

${ }^{81}$ Torabully, Voices from the Aapravasi Ghat, 54.
} 
when it was whole." ${ }^{82}$ Like Walcott, Torabully highlights the profound desire for a revered wholeness in the face of an existence characterized by fractures and discontinuities. As evidenced in the verses cited above from Torabully's poetry, this totality, which immediately contrasts the fakir's fragmented reality, is not envisioned as a counterintuitive ossified structure as symbolized by Walcott's vase; instead it is evoked as "sap" and "honey." These fluid substances, produced as a result of processes, connote vitality, amorphousness, and mutability. The fakir's fluid identity is moreover represented as borderless and beyond categorization: "A fakir was always beyond borders, / Lifting his pains over endless splinters." ${ }^{~} 3$ As previously discussed, the diverse meanings attributed to the term fakir, in effect, renders the fakir powerful and conveys a reflection of divine power and splendor, as the poet indicates, "Variety is a sign of Unique Divinity." 84

The fakir, with his identity always in a state of suspension, composition, reinvention, and relation with its surroundings, can therefore be considered a human embodiment of Coolitude and, by extension, personified coral: "A fakir is a person so many, / A contortion of facets in identity - / He is coral made human." 85 The fakir, as one who constantly reinvents his sense of self beyond multiple barriers, manifests himself as a metonym for limitless possibilities of identity. In this respect, the fakir is a figure in motion, a balancing act of the vision of identity at the core of Torabully's Coolitude. He negotiates between balance and imbalance and contorts the multiple layers of his identity to their utmost physical and transcendental limits. Torabully continues to construct the composite and mosaic identity of the character asking, "What is a fakir's identity / In a homogenous society? / Am I the sin of fluidity / Or symbol of heterogeneity?" 86 . The usage of end rhymes in this verse, while creating rhythm, reflects a homogeneity that the poet contradicts with the rhetorical questions posed in response to the inquiry about the fakir's identity. By not providing definitive responses, Torabully emphasizes the fakir as a coral being whose multi-layered selves embody opacity, in the Glissentian sense of the term. Not fully understanding but accepting the fakir's circumvolutions is, for Torabully, an integral part of multicultural exchanges whereby an encoded ambiguity remains intact to undermine cultural transparency and foster diversity.

\footnotetext{
${ }^{82}$ Derek Walcott, What the Twilight Says: Essays (New York: Farrar, Straus and Giroux, 1998), 69.

${ }^{83}$ Torabully, Voices from the Aapravasi Ghat, 58.

${ }^{84}$ Ibid., 60.

${ }^{85}$ Ibid., 85

${ }^{86}$ Ibid., 78.
} 
In the final stanza of this collection, Torabully describes the fakir in the following manner: "The fakir has a particular organization of geometry. / hIS body is a composite sign. / None of hIs gestures is benign. / Beware of those who reduce HIs body / To its sheer border of skin race and poverty!" 87 This evocation of geometric designs in reference to the fakir's identity hints at the relational, complex, opaque, and mosaic construction of his sense of being, which defies archaic approaches that reference phenotype and socio-economic status to define individuals. This resistance to fixed and immobile identity constructions is reinforced textually with Torabully's usage of concise verses, each of which ends with a period and finally an exclamation point to create a dramatic effect that conveys an expression of resoluteness.

More importantly, Torabully exemplifies that "particular organization of geometry" on a textual level through the ostensibly random capitalization of letters in the possessive pronoun "his." The unconventional capitalization of specific letters within the word "his" breaks with established grammatical rules to create a new poetic form that follows its own set of specific rules and structures. This poetic non-conformity harkens back to a passage earlier in the collection where the fakir says, "I called the troubadour my own qawali, / Saying: 'Fit my structure sir, / I refuse the system of your metre, / I shun the length of rhythm and your nature. LITERATURE / IS MY NEW VENTURE." 88 Although the structure in the final stanza of the collection may seem arbitrary, it follows, in effect, a consistent and rhythmic arrangement reinforcing the poet's insistence that none of the fakir's gestures is meaningless. To facilitate the understanding of the poetic pattern at work here, it may be best to demonstrate it with a diagram. To represent lowercase letters, I will use underscores ( $\left.{ }_{-}\right)$and for uppercase letters, em dashes ( - ). Using this key, the words "hIS," "hIs," "HIs," as they appear in the text, create the following pattern:____________. From this composite pattern, there is an underlying logic to what initially seems to be illogical. Within the apparent lexical disarray, all of the separate elements come together to form a reassembled mosaic pattern, reinforcing the idea of the fakir as a contortionist who constantly negotiates between balance and imbalance and pushes his social and physical being to its limits. Moreover, Torabully's choice to use the possessive pronoun "his" to highlight that pattern increases the fakir's sense of ownership and agency of his physical manifestation. The fakir's body, which symbolizes diversity, limitless possibilities, fragmentation, opacity, and non-conformity, also parallels Torabully's poetic body of

${ }^{87}$ Ibid., 154.
${ }^{88}$ Ibid., 77. 
text, in which the poet offers his own diverse counter narrative of history and counter poetics.

Torabully's poetry serves as a tribute to nuanced postcolonial identities that claim diversity as a source of its strength, and perhaps even its uniqueness. It emphasizes subtleties and various layers of meaning that come together to create unparalleled connections and foster practices of humanism. Certainly, Torabully writes against attempts to associate the indentured laborers' experience exclusively to the Indian diaspora in Mauritius. But his poetic engagement with the fakir seems to be reproducing the very Indo-centrism that he is challenging since this figure foregrounds a cultural repertoire with which non-Indo-Mauritians may not connect. The fakir remains a quintessential symbol of the Indian holy man, which places him within a specific spatiotemporal, religious, and socio-cultural context that disconnects from the postcolonial indentured diasporic experience. Moreover, Torabully's poetic emphasis on the fakir undoes his earlier attempts to recognize the female indentured experience and produces a biased gendered perspective. Although the reference to the fakir figure introduces a limitation to Torabully's poetic disruption and vision of multiculturalism, he seems, however, more inspired by and concerned with how identities can move beyond its physical, ethnic, racial, and religious boundaries and open up to newer realms of possibilities predicated on fluidity, dynamism, openness, and unpredictability.

Torabully's collection closes with an image depicting a man climbing what looks like a rope ladder. It is a full upshot that captures trees on either side of the ladder. The vastness of the open sky can be seen in the background. The caption below the image indicates that it is a photo of popular entertainment in a village located in the north of Mauritius during the late 1950s. ${ }^{89}$ Another image used at the very beginning of this work simultaneously contrasts and complements the photo. This first image depicts a ship anchored in front of the Aapravasi Ghat during the time of indentureship and is representative of the symbolic arrival of indentured laborers in Mauritius, cultural separation from their homeland, and historical erasure. In the final image, the rope ladder is reminiscent of the symbolic steps that led to the Aapravasi Ghat and facilitated the entrance of the indentured laborers into Mauritius. The ladder is not connected to the ocean but rather rises up into the open sky. The depiction of the climbing man harks back to the poet's earlier text in which he urges those belonging to the indentured diaspora to persist in being. More importantly, it suggests the metaphorical ascendance

\footnotetext{
${ }^{89}$ Ibid., 155.
} 
from a terrestrial space to a subliminal space that is replete with open and limitless possibilities.

\section{CONCLUSION}

In contemporary Mauritius, the Aapravasi Ghat has come to symbolize the Indian diasporic experience. Its local recognition and international positioning as a World Heritage site raise questions about cultivating a singular Indo-centric narrative that creates hierarchical and divisive socio-political and cultural structures. However, Torabully's Voices from the Aapravasi Ghat: Indentured Imaginaries revisits the site and produces a counter poetics. Through his engagement with the Aapravasi Ghat and its metaphorical meanings, Torabully recuperates the indentured experience and writes it into postcolonial discourses. More significantly, he articulates historical and cultural specificities to ultimately challenge and revise exclusivist histories related to indentureship.

As part of his revisionist poetics that foregrounds particularities, Torabully is attuned to the holistic experience of indentureship. He does not in any way deny the atrocities, deception, and victimization that encompassed this experience, but he is also sensitive to the positive possibilities that are born out of indentureship. He constructs the Aapravasi Ghat as a material archive and international symbol of the system of indentured servitude and the ethnic, racial, and linguistic diversity that defined it. Through his engagement with the site, he undoes selective silencing and stresses the multiple identities that comprised the indentured diaspora. He extracts the creative and symbolic potential of the Aapravasi Ghat and positions it as a space that reflects his poetics of Coolitude. As part of his Coolitude agenda, Torabully engages with the complexity, diversity, and dynamism inherent in the indentured experience and rewrites considerations on the indentured diaspora that tended to project a singular Indian narrative. He uses the Aapravasi Ghat as a didactic space that reexamines the indentured identity and history and makes connections between people that traverse racial, cultural, geographical, and socio-economic borders in an attempt to bridge ethnic divisions. Through his poetry, he posits the Aapravasi Ghat as a realm of indentured memory that projects into the future as a force that catalyzes fresh perspectives, pursues humanistic aspirations, and forges reinvented identities founded on plurality, openness, and fluidity. 